\title{
Uzbek scientists masterpieces in world funds
}

\author{
Rajabova Rohila Zakirovna ${ }^{1}$ \\ ${ }^{I}$ Islamic History and Source Studies, PhD student of the Department of Philosophy, \\ Bukhara State University, Uzbekistan \\ Email:rajabova r@umail.uz
}

\begin{abstract}
Annotation. Studying and preserving the manuscripts, each of which has a great spiritual heritage, is a masterpiece of culture, and today this article not only promotes the study of manuscripts, but also explores the importance of the study of manuscripts not only in our country but around the world.
\end{abstract}

Keywords: Manuscript works, source, history, ancient monument, culture, nation, ideology.

\section{INTRODUCTION}

During the years of independence great work has been done and is being continued to restore the ancient history and rich culture of our people, to thoroughly study and popularize the scientific, religious and spiritual heritage of our great thinkers and saints. At the same time, the need to increase the effectiveness of the reforms in the spiritual and educational sphere calls for a qualitatively new level of work in this area. In this regard, it is important to improve the activities of the Abu Rayhon Beruni Institute of Oriental Studies of the Academy of Sciences of the Republic of Uzbekistan, as well as institutions of ancient written sources, which are unique not only in our country but also worldwide.

Uzbekistan has been the richest manuscript in Central Asia for centuries, most of which is kept at the Abu Rayhan Beruni Institute of Oriental Studies at the Academy of Sciences of Uzbekistan. This manuscript is a treasure trove of great importance worldwide. The Fund was included in the UNESCO World Heritage List in 2000 as a unique scientific and cultural site. The Institute's manuscript fund consists of six separate chapters, comprising 26,000 manuscripts in Arabic, Persian, Old Uzbek, and other Oriental languages, 39,000 volumes, and about 10,000 historical documents.

The Alisher Navoi State Literature Museum is a cultural, educational and scientific place that manuscripts, various documents, pictures, memories, photographs, and exhibits related to the life and creative activities of many centuries of Uzbek literature. A great deal of work is being done on the publication and cataloging of manuscripts and printed books from these funds, which is an important stage in the scientific circulation.

\section{LITERATURE REVIEW}

Meeting of the President Shavkat Mirziyoyev with leading scientists of the country, Presidential Decrees aimed at reforming a number of research institutions in the Academy of Sciences, improving their material and technical base, training abroad, expanding cooperation with foreign scholars. led a new phase of research With a new enthusiasm, a system of measures for the comprehensive study and promotion of our manuscript heritage is being developed.

Decree of the President of the Republic of Uzbekistan "On measures to further improve the system of preservation, research and propagation of ancient written sources for the purpose of national self-awareness, preservation of historical memory, preservation, enrichment and research of the great written heritage and popularization of cultural and spiritual values" The decision was made.

This decision is aimed at raising the young generation with a deep respect for patriotic and rich history, as well as further strengthening the international prestige of Uzbekistan as a country that has made a significant contribution to the development of world science and culture, preserving, studying and widely promoting our rich written heritage. .

In particular, these prestigious research institutions will be able to preserve and restore manuscripts, enrich existing funds, create favorable conditions for domestic and foreign researchers to work with 
historical sources, in-depth study of historical and cultural heritage of our great scientists and thinkers. To promote the invaluable contribution to the development of civilization, to bring up our compatriots, and first of all, the younger generation in the spirit of respect for the great spiritual heritage of our people, love and devotion to the native land. It is worth noting that there are urgent tasks to radically improve the efficiency of the work.

\section{MAIN PART}

The increasing attention to the preservation and restoration of manuscripts can be traced not only in Uzbekistan, but also worldwide. After all, the study of written sources not only informs us of our culture, spirituality, and history, but also plays an important role in strengthening our intellectual potential.

As a result of the introduction of Islam in our country, the ideological importance of the Arabic language has increased among the local population. Until that time our country has been a center of dialogue between the Turkic and Persian-speaking people since ancient times. Until the 18th and 19th centuries most of the religious sources were in Arabic. In later centuries, sources (especially mystic works) were written mainly in Persian. Works in Arabic have been commented on and written in Persian. Our ancestors have been leaders in the history of religious sciences, especially in the fields of hadith, jurisprudence, kalam and mysticism. Today, there is a great opportunity to study the life and works of Islamic scholars and to publish their works. All these good deeds that please our people are the result of wise, pathetic, far-sighted policy pursued by the President of the Republic. After all, we always appreciate the fact that Islam is the religion of our ancestors, and that it is faith, morality, religion and enlightenment for us. The works of our scholars play an important role in modern understanding of religion, revealing the true ideals of humanism and tolerance of Islam, and bringing them to our people in a pure way. In the revival of our present national and religious values, it is important to thoroughly study and analyze the scientific heritage of our scholars, which is our spiritual enlightenment.

Rare manuscripts about the scientific heritage of many Uzbek scientists are kept not only in our country, but also in libraries and museums abroad. Malaysian research centers, museums and libraries are a good example of this. The Museum of Islamic Culture in Malaysia contains more than 15,000 religioushistorical exhibits on Islamic culture and history. The museum has more than 3,000 books, and about 1,000 of them are manuscripts. Among the unique exhibits preserved are three manuscript copies of Bukhara calligraphy and a book by Imam Bukhari's Al-Jome' al-Sahih, Fath al-Bari fi City Sahih alBukhari, and Daloil Al-Bukhari Calligraphy.”.

The Malaysian National Library contains more than 5,000 manuscripts, including about 200 Arabic and Persian manuscripts and 253 pages, including Sahih Al-Bukhari. A manuscript written by Ali Abu Amr Abyari, written in 1265 A.D., is one of the rare pearls of the library and is related to the science of logic and puberty.

\section{DISCUSSION}

In the library of the International Islamic University of Malaysia, more than 500 rare manuscripts of Maveraunnahr scholars are found. The oldest and unique manuscript in the fund is a copy of the Holy Quran manuscript copied by calligrapher Muhammad Khayriddin (d. 866). The size of the work is $30 * 40$ and is a rare manuscript with 12 lines on each page, each containing a series of golden water and a series of ink. This work is from Samarkand.

In addition, the Institute of Oriental Manuscripts of the Russian Academy of Sciences also retains dozens of priceless manuscripts from Uzbekistan, or rich cultural heritage of the Uzbek people. One of these is a copy of the Qur'an in the eighth century CE, transcribed in the Arabic alphabet letter. Several pages of the manuscript are kept in Uzbekistan, Tashkent and Bukhara. The whereabouts of the remaining pages are still unknown. According to sources, the book was once stored in the Big Langar village of Kamashi district of Kashkadarya region, in the room of the sheikhs of the Sufi teaching. Therefore, this manuscript is known as the "Large Langar Quran" among the scientific community. There is a variation on how much of the book, 81 pages, went to Russia. It was introduced to the Institute of Oriental Manuscripts at the end of the 1930s. Recent research by a number of scholars has revealed that the pages 
kept in Uzbekistan and Russia are just parts of the same manuscript, which were actually copied 13 centuries ago. According to experts, it is one of the oldest and most respected copies of the Qur'an in the Islamic world.

\section{CONCLUSION}

In conclusion, it is necessary to study and research these unique manuscripts, and today there are thousands of manuscripts about the scientific heritage of our scholars in the world manuscript funds. Their study and research is a task we are facing for young people like us, who are waiting for their researchers. As President Shavkat Mirziyoev said, "We will study it even if a page is written about the spiritual heritage of our great ancestors."

\section{REFERENCES}

1. Arabic manuscripts. Institute of Oriental Studies, Academy of Sciences of the USSR. Short catalog. M .: publishing house "Science" the main edition of oriental literature, 1986.-526s.

2. Bartold V.V. The history of the cultural life of Turkestan // Works. T.II.-M.: Science. 1963.

3. V.V. Bartold. Works on the history and philology of Turkic and Mongolian peoples. - M .: Oriental literature of the Russian Academy of Sciences, 2002. - 762 S.

4. Akhmedov B. Historical and geographical literature of Central Asia XVI-XVIII centuries. (written monuments). - T .: Fan, 1985.

5. Kurbanov G.N. Bukhara press XVII-beginning of XX centuries (Catalogs). - T .: Uzbekistan, 1987.

6. M. Imomnazarov, M. Eshmuxamedova. Basis of national spirituality T., 2001 